\title{
Educational Encouragement, Parenting Styles, Gender and Ethnicity as Predictors of Academic Achievement among Special Education Students
}

\author{
Aqeel Khan ${ }^{1}$, Roslee Ahmad ${ }^{1}$, Abdul Rahim Hamdan ${ }^{1} \&$ Mohamed Sharif Mustaffa $^{1}$ \\ ${ }^{1}$ Faculty of Education, Universiti Teknologi Malaysia, Johor Bahru, Malaysia \\ Correspondence: Aqeel Khan, Faculty of Education, Universiti Teknologi Malaysia (UTM), Skudai, 81310 Johor \\ Bahru, Malaysia. Tel: 601-0787-2284. E-mail: draqeelkhan@gmail.com
}

Received: November 6, 2013 Accepted: December 18, 2013 Online Published: January 15, 2014

doi:10.5539/ies.v7n2p18

URL: http://dx.doi.org/10.5539/ies.v7n2p18

\begin{abstract}
Current study examines the predictors' of academic achievement: role of parenting styles, educational encouragement, gender and ethnicity among special education students. Participants of this study consisted 200 special education students ( $\mathrm{N}=105$ boys and $\mathrm{N}=95$ girls) age varies 14 to 19 years from one school located at Kuala Lumpur, Malaysia. Results showed authoritative parenting styles were mostly used by the parents of their special education students. Significant relationships were existed in parenting styles, educational encouragement and academic achievement among special educational students. Educational encouragement from mother, father, sibling and friends, ethnicity and gender were found to be significant predictors for academic achievement. Findings of current research suggested parenting styles and educational encouragement contribute to special education student's academic achievement. The results of the current study provide the insight for the educators, teachers and parents dealing with special education adolescents.
\end{abstract}

Keywords: parenting, encouragement, achievement

\section{Introduction}

Existing literature highlighted the positive effects of parental encouragement on children's academic success, these studies have revealed the benefits of parental encouragement in both academic (Astone \& McLanahan, 1991; Fehrmann et al., 1987; Keith et al., 1993; Lee, 1994; Muller, 1993; Sui-Chu \& Willms, 1996) and non-academic domains (Epstein, 1992; Sui-Chu \& Willms, 1996; Stevenson \& Baker, 1987). Present study focuses on parent's contribution to their children's success by helping with homework, guiding students in their choice of courses, and implicitly and explicitly encouraging school success by setting and maintaining high standards. Parenting style plays an important role in the area of social and educational development (Leung, 1988), it influences a child's success in many domains such as academic achievement (Darling, 1999). It is considered an important cause of several aspects of children's outcome (Gadeyne et al., 2004). To date, longitudinal research on the relationship between parental styles and academic achievement has examined connection in children and adolescents. Authoritative parenting (high acceptance, supervision, and granting of psychological autonomy) has been shown to foster school performance; such relationship may reflect a variety of specific education-related parenting behaviors (Patterson \& Yoerger, 1991). For facilitating academic performance, such as encouragement for achievement and participation in school activities have been found to be more common in authoritative parents (Bogenschneider, 1990). Several of these factors were addressed in research by Steinberg et al. (1992), who studied a large, ethnically and socioeconomically diverse sample $(\mathrm{N}=$ 64,000) of U.S. students aged 14-18 years. Their findings showed authoritative parenting was associated both with higher student achievement and with greater involvement in school-related activities. Catsambis (1998) reported parental involvement and encouragement influenced the educational achievements of high school seniors. However the parenting for the normal children can be easy, but if it includes children who afflicted with disabilities becomes challenging. Raising a child with a learning disability is definitely a challenging task. Learning disabilities rarely completely cured. But with proper parenting and encouragement, many children with learning disabilities can improve their living skills.

Parenting style characterizes standard strategies that parents use in their child rearing. Parenting style relates to 
the behaviors used by parents to socialize and control the actions of their child (Lightfoot et al., 2009). Baumrind (1967) stated three parenting styles which are authoritarian, authoritative and permissive. In authoritarian parenting style parents control and evaluate their children by their attitudes and behaviors with a mode of rules and regulations. Authoritative parenting style parents established a clear setting of standard and expectation of mature behavior from their children. In permissive parenting style parents who are perceived to be accepting of their children's demands and giving high freedom to their children (Dornbusch et al., 1987). Bhatnagar and Sharma (1992) observed relationship between parental involvement and students' academic achievement. Kordi and Baharudin (2010) parents will influence student's school achievement, especially with the parents who involved in the education of the student and monitor their school homework in house. Authoritative parenting styles have positive relationship with the students' academic achievement (Baumrind, 1967; Dornbusch et al., 1987; Steinberg et al., 1989; Steinberg et al., 1991). Baumrind (1967) reported that children who had authoritative parent were more active, achievement-oriented and independent compared with children who had non-authoritative parent. Preschool children with authoritative families were consistently and significantly more competent than other children (Baumrind \& Black, 1967). Baumrind (1991) found authoritative parenting had children who were academic successful, responsible, independence and mature. Ishak et al. (2012) reported an authoritative parenting style showed the impact on the academic achievement. Mostly parent in Malaysia practiced the authoritative parenting styles (Keshavarz \& Baharudin, 2009). In the result, it is stated that parents were able to influences the children's development. Vellymalay (2013) suggested strong relationship between parents' education and their involvement on children's education. Gonzalez and Padilla (1997) student's environment at home/school directly influence on student's academic achievement. Parental encouragement in education, as well as support can effect a student's motivation to continue in education. Steinberg (1992) suggested that involvement or encouragement from parent may be influenced the adolescents in their academic success when it is only appear an overall authoritative parenting style in home.

This study answers the following research questions: (a) Among Authoritarian and Authoritative, which types of parenting styles was the most frequently used by parents to deal with special education children? (b) Among the educational encouragement from mother, father, friend and teacher, which source of educational encouragement reported highest among special education children? (c) Is there any significant relationship in the dimensions of educational encouragement, parenting style and academic achievement among special education children? (d) To what extent gender, ethnicity, educational encouragement and parenting style predicting academic achievement among special children?

\section{Method}

\subsection{Participants}

The participants of this study consisted of 200 special education students (105 boys and 95 girls) from age 14 to 19 in one of the school in Kuala Lumpur. It was confirmed that students have learning disabilities by government hospital. Participants belong to Chinese ethnic group was $\mathrm{N}=80$, followed by Malay which was $\mathrm{N}=65$ and Indian $\mathrm{N}=55$. The school was one of the schools who have Special Education Programs Integration in Kuala Lumpur, Malaysia.

\subsection{Procedures}

Prior to administration of the study the consent from the participants for participating in the study were obtained and proper rapport was developed with the respondents by explaining the importance and the relevance of the study. The subjects were assured that their responses would be kept confidential and will be utilized only for the purpose of research. They were asked to fill up the questionnaire by themselves according to the instructions written on the top of the questionnaire.

\subsection{Measures}

(1) Parenting Practices Questionnaire (PPQ) by Robinson et al., 1995, it consists of three parenting styles of authoritarian, permissive, and authoritative. The questionnaire includes 52 items based on three parenting styles. This questionnaire often used in examining parenting styles in relation with child's outcome such as academic achievement. Authoritarian items have a Chronbach alpha of .86, permissive items have a Chronbach alpha of .75, and authoritative items have a Chronbach alpha of .91 (Robinson et al., 1995).

(2) Educational Encouragement Scale; Gloria and Rodriguez (2000), Evans (1995), Dreikurs, Grunwald, \& Pepper (1982) consists of $22 \mathrm{mix}$ items of two educational encouragement scale measuring four sources of educational encouragement provided by fathers ( 6 items), mothers (6 items), friends ( 5 items), and teachers ( 5 items), for example, "I think you can do it. The 5-point rating scale had anchors of 1: Strongly Disagree to 5: 
Strongly Agree. Scores on each category of support were added. Possible range of scores was from 22 (low educational encouragement) to 110 (high educational encouragement). Thus higher scores state higher level of educational encouragement. The scale showed good internal consistency, as evidenced by an alpha coefficient of .88 in the present study.

(3) Academic Achievement: Academic achievements were assessed from their last exam grades.

(4) Personal Data Sheet: Gender, Ethnicity, Age, Academic CGPA.

\section{Results}

Table one presents the mean values, cronbach's alpha reliability and inter-correlation matrix. Results showed positive relationship of academic achievement with educational encouragement (from mother, father, parents and teachers) and authoritarian parenting styles. Significant positive correlations showed authoritarian parenting styles, educational encouragement playing key roles in academic achievement. In Table two beta weights representing relative contributions of each of the predictor variables on the prediction of special education students' academic achievement; gender, ethnicity, educational encouragement (from mother, father, parents and teachers) and parenting style significantly predicting academic achievement.

Table 1. Correlations of academic achievement with dimensions of educational encouragement and parenting style

\begin{tabular}{llllllllllll}
\hline & $\mathrm{M}$ & $\alpha$ & 1 & 2 & 3 & 4 & 5 & 6 & 7 & 8 \\
\hline Academic Achievement (1) & 6.02 & .87 & 1 & & & & & & & \\
Educational Encouragement (2) & 7.12 & .91 & $.21^{*}$ & 1 & & & & & & \\
Encouragement from Mother (3) & 11.76 & .89 & $.38^{* *}$ & $.57^{* *}$ & 1 & & & & & \\
Encouragement from Father (4) & 07.77 & .88 & .08 & $.57^{* *}$ & -.13 & 1 & & & & \\
Encouragement from Friends (5) & 07.99 & .92 & $.16^{*}$ & $.66^{* *}$ & $.23^{*}$ & .15 & 1 & & & & \\
Encouragement from Teachers (6) & 07.87 & .86 & .03 & $.63^{* *}$ & $.29^{* *}$ & $.26^{* *}$ & $.20^{*}$ & 1 & & \\
Authoritarian parenting (7) & 05.43 & .83 & $.30^{*}$ & $.30^{* *}$ & .12 & $.31^{* *}$ & .15 & .09 & 1 & \\
Authoritative parenting (8) & 08.69 & .86 & .05 & $.28^{* *}$ & $.61^{* *}$ & .18 & -.09 & $-.18^{*}$ & $-.30^{* *}$ & 1 \\
\hline
\end{tabular}

* Correlation is significant at the 0.05 level (2-tailed).

** Correlation is significant at the 0.01 level (2-tailed).

Table 2. Representing predictors of academic achievement: gender, ethnicity, educational encouragement and parenting style

Dependent Variable: Academic Achievement

$\beta$ Std. Error t Significant

\begin{tabular}{lrrrr}
\hline Gender & .197 & .083 & 2.10 & .043 \\
Ethnicity & .232 & .034 & -2.40 & .033 \\
Encouragement & .210 & .048 & -1.07 & .035 \\
Parenting Style & .326 & .026 & 1.30 & .000 \\
\hline
\end{tabular}

$\mathrm{R}$ Square $=.308$

\section{Discussion}

Findings clearly showed that authoritarian parenting styles and educational encouragement plays important role in special education children's academic achievement. These findings were consistent with Elias and Tan (2009) 
suggested majority of the students perceived both paternal and maternal parenting style as authoritative. Past researches suggested that majority of the samples perceived their parents as authoritative (Fletcher et al., 1999; Shahimi et al., 2013; Lim, 1998). It can be discussed with possible reasons regarding the present results obtained. Parents of special education students were more sensitive to their children's needs, able to understand children's abilities and behaviors from a children's perspective, and to use good manner parenting strategies in guiding to their children. Parent with authoritative style also give freedom to their children. When the children get low academic achievement, the authoritative parents usually encourage them to try harder and offer support, motivation, and also practicing and conveying more loving words. This was supported by Belsky's (1984) model showed direct link between parenting and child outcome. Keshavarz and Baharudin (2009) also believe authoritarian parenting style is widely accepted by majority of Malaysian parents regardless of ethnic races.

Educational encouragement from mother found to be the highest as compare to father, peers and teachers (Khan, 2012). It proves that mother is the one who encourage the special children more in their education. Mother usually spends more time with the special children after school. Mother's involvement was found to be direct interaction, convenience and responsibility. It was supported by McBride and Mills (1993) suggested that fathers spent less time with their children in their activities. Mothers showed a higher average share of responsibility if comparing with fathers (Leslie, Anderson, \& Branson, 1991; Peterson \& Gerson, 1992). It seems a nature that mothers are more caring towards their children. Since mother carries the child for 9 months by providing breast feed and in most of the culture, mother as the primary care givers for the early developmental years. The finding showed significant relationship on academic achievement, educational encouragement from parent, peers except educational encouragement from teachers. The finding of the research was consistent with some of the previous researches (Sophia, 1998; Plunkett et al., 2008), in which they found that parental involvement shows positive relationship on academic achievement. For the special education student, they have limitation on their ability. Educational encouragement is one of the external factors in improving the special education students' academic achievement.

The findings also showed authoritative parents shows positive relationship with educational encouragement to special education students. However, the finding of this research supported by Steinberg et al. (1992), who found authoritative parenting involvement was higher with encouragement to the children on their academic achievement. Authoritative parents were more likely to be involved in helping school homework and more likely to encourage academic excellence (Bogenschneider, 1990). In general, studies indicate that students whose parents were more involved in their education earn higher grades in school (Stevenson \& Baker, 1987).

Findings showed parenting style, educational encouragement, ethnicity and gender were found to be significant predictors of academic achievement among special education students (Liew, 2009). However 30.8\% of the variation in academic achievement can be explained by the gender, ethnicity and educational encouragement and rest can be explained by heritability and other factors like personality, which could be studied in future researches.

Parenting practices and school performance has been limited to studies of children and young adolescents (e.g., Patterson \& Yoerger, 1991; Steinberg et al., 1989). Authoritative parents were found to be more likely to participate in school activities and to encourage academic excellence (Bogenschneider, 1990). Authoritative parenting (high acceptance, supervision, and granting of psychological autonomy) led to better school performance and stronger engagement with school-related activities among adolescents. Parental authoritativeness has been associated with higher levels of school involvement and greater encouragement of academic success. In contrast, parental encouragement of academic success did not seem to play a direct role in facilitating adolescent school performance or engagement after accounting for parental involvement (Steinberg et. al., 1992).

The role of parental encouragement has been demonstrated in research based on the Wisconsin Status Attainment Model (e.g., Sewell \& Hauser, 1980). Furthermore, findings showed that parental encouragement in adolescents' education associated with higher grades (e.g., Stevenson \& Baker, 1987). Parental support and encouragement was found to be important antecedent to the development of positive attitudes by students towards themselves and their life circumstances (Barber et al., 1994; Barber \& Thomas, 1986; Felson \& Zielinski, 1989; Khan, 2013). Limitation of the study could be this research was based on students self-report of the perception of their parental styles and not their parents' perception for parenting. Future research should look more into authoritarian parenting styles of students with larger sample, which may represent Malaysian students. 


\section{References}

Astone, N. M., \& McLanahan, S. S. (1991). Family structure, parental practices and high school completion. American Sociological Review, 56, 309-320. http://dx.doi.org/10.2307/2096106

Barber, B. K., \& Thomas, D. L. (1986). Dimensions of fathers' and mothers' supportive behavior. The case for physical affection. Journal of Marriage and the Family, 48, 783-794. http://dx.doi.org/10.2307/352571

Barber, B. K., Olsen, J. E., \& Shagle, S. C. (1994). Associations between parental psychological and behavioral control and youth internalized and externalized behavior. Child Development, 65, 1116-1132. http://dx.doi.org/10.2307/1131309

Baumrind, D. (1967). Child care practices anteceding three patterns of preschool behavior. Genet. Psychol. Monogr, 75, 43-88.

Baumrind, D. (1991). Parenting styles and adolescent development. In J. Brooks-Gunn, R. Lerner, \& A. C. Peterson (Eds.), The Encyclopedia of Adolescence, Garland, New York (pp. 746-758).

Baumrind, D., \& Black, A. E. (1967). Socialization practices associated with dimensions of competence in preschool boys and girls. Child Development, 38, 291-327. http://dx.doi.org/10.2307/1127295

Belsky, J. (1984). The determinants of parenting: A process model. Child Development, 55, 83-96. http://dx.doi.org/10.2307/1129836

Bhatnagar, J. K., \& Sharma, M. (1992). A study of the relationship between parental and academic achievement in a semi-rural setting. Psychological. Studies, 37, 126-129.

Bogenschneider, K. (1990). Maternal employment and high school achievement: Mediators, moderators, and developmental effects (Unpublished doctoral dissertation. Department of Child and Family Studies, University of Wisconsin-Madison).

Catsambis, S. (1998). Expanding knowledge of parental involvement in secondary education. Retrieved December 6, 2005, from http://www.csos.jhu.edu/crespar/techRepofisRepofi27.pdf

Darling, N. (1999). Parenting styles and its correlates (ERIC Document Reproduction Service No. ED 400517).

Dornbusch, S. M., Ritter, P. L., Leiderman, P. H., Robert, D. F., \& Fraleigh, M. J. (1987). The relation of adolescent parenting style to adolescent school performance. Child Development, 58, 1244-1257. http://dx.doi.org/10.2307/1130618

Dreikurs, R., Grunwald, B., \& Pepper, F. (1982). Maintaining sanity in the classroom. New York: Harper \& Row.

Elias, H., \& Tan, H. Y. (2009). Relationship between perceived paternal and maternal parenting styles and student academic achievement in selected secondary schools. European Journal of Social Sciences, 9, 181-192.

Epstein, J. L. (1992). School and family partnerships. In M. Alkin (Ed.), Encyclopedia of educational research (6th ed.). New York: MacMillan.

Evans, T. (1995). The encouraging teacher. In G. M. Gazda, F. Asbury, M. Blazer, W. Childers, \& R. Wallers (Eds.), Human relations development (5th ed., pp. 261-269). Boston: Allyn \& Bacon.

Fehrmann, P. G., Keith, T. Z., \& Reimers, T. (1987). Home influence on school learning: Direct and indirect effects of parental involvement on high school grades. Journal of Educational Research, 806, 330-337.

Felson, R., \& Zielinski, M. (1989). Children's Self-esteem and Parental Support. Journal of Marriage and the Family, 51, 727-735. http://dx.doi.org/10.2307/352171

Fletcher, A. C., Steinberg, L., \& Sellers, E. B. (1999). Adolescents' Well-Being as a Function of Perceived Interparental Consistency. Journal of Marriage and the Family, 61, 599-610. http://dx.doi.org/10.2307/353563

Gadeyne, E., Ghesquie're, P., \& Onghena, P. (2004). Longitudinal relations between parenting and child adjustment in young children. Journal of Clinical Child and Adolescent Psychology, 33, 347-358.

Gloria, A. M., \& Rodriguez, E. R. (2000). Counseling Latino university students: Psychosociocultural issues for consideration. Journal of Counseling and Development, 78,2 , 145-154. http://dx.doi.org/10.1002/j.1556-6676.2000.tb02572.x

Gonzalez, R., \& Padilla, A. M. (1997). The academic resilience of Mexican American High School Students. 
Hispanic Journal of Behavioral Sciences, 19, 301-317. http://dx.doi.org/10.1177/07399863970193004

Ishak, Z., Low, S. F., \& Lau, P. L. (2012). Parenting style as a moderator for students' academic achievement. Journal of Science Education and Technology, 21, 487-493. http://dx.doi.org/10.1007/s10956-011-9340-1

Keith, Z. T., Keith, P. B., Troutman, G. C., Bickley, P. G., Trivette, P. S., \& Singh, K. (1993). Does parental involvement affect eighth-grade student achievement? Structural analysis of national data. School Psychology Review, 22, 474-496.

Keshavrz, S., \& Baharudin, R. (2009). Parenting style in collectivist culture of Malaysia. European Journal of Social Sciences, 10, 66.

Khan, A. (2012). Sex Differences' in Educational Encouragement and Academic Achievement. Psychological Reports, 111, 149-155.

Khan, A. (2013). Predictors of Positive Psychological Strengths and Subjective Well-being among North Indian Adolescents: Role of Mentoring and Educational Encouragement. Social Indicators Research, 114, 3, 1285-1293.

Kordi, A., \& Baharudin, R. (2010). Parenting attitude and style and its effect on children's school achievements. International Journal of Psychological Studies, 2, 217-222.

Lee, S. (1994). Family-school connections and student's education: continuity and change of family involvement from the middle grades to high school (Unpublished Doctoral dissertation, Johns Hopkins University, Baltimore, MD).

Leslie, L. A., Anderson, E. A., \& Branson, M. P. (1991). Responsibility for children: The role of gender and employment. Journal of Family Issues, 12, 197-210. http://dx.doi.org/10.1177/019251391012002004

Leung, K., Lau, S., \& Lam, W. (1988). Parenting styles and academic achievement: A cross-cultural study. Journal of Developmental Psychology, 44, 157-172.

Liew, H. P. (2009). Ethnicity and Academic Achievement by Malaysian Eighth Grade Students (Unpublished Doctoral dissertation). Retrieved from http://gradworks.umi.com/3366297.pdf

Lightfoot, C., Cole, M., \& Cole, S. (2009). The development of children. New York, NY: Worth Publishers.

Lim, A. L. (1998). Perceived parenting styles and academic achievement of selected Malaysian form four students (Unpublished Master thesis, Universiti Malaya, Kuala Lumpur, Malaysia).

McBride, B. A., \& Mills, G. (1993). A comparison of mother and father involvement with their preschool age $\begin{array}{lllll}\text { children. Early } \quad \text { Childhood Research } & \text { Quarterly, }\end{array}$ http://dx.doi.org/10.1016/S0885-2006(05)80080-8

Muller, C. (1993). Parent involvement and academic achievement: an analysis of family resources available to the child. In B. Schneider, \& J. S. Coleman (Eds.), Parents, their children, and schools (pp. 77-113). Boulder, Co: Westview Press.

Patterson, G., \& Yoerger, K. (1991). A model for general parenting skill is too simple: Mediational models work better. Paper presented at the biennial meetings of the Society for Research in Child Development, Seattle.

Peterson, R., \& Gerson, K. (1992). Determinants of responsibility for childcare arrangements among dual-earner couples. Journal of Marriage and Family, 54, 527-536.

Plunkett, S. W., Henry, C. S., Houltberg, B. J., Sands, T., \& Abarca-Mortensen, S. (2008). Academic support by significant others and educational resilience in Mexican origin ninth grade students from intact families. Journal of Early Adolescence, 28, 333-355. http://dx.doi.org/10.1177/0272431608314660

Robinson, C., Mandleco, B., Olsen, S. F., \& Hart, C. H. (1995). Authoritative, authoritarian, and permissive parenting practices: Development of a new measure. Psychological Reports, 77, 819-830. http://dx.doi.org/10.2466/pr0.1995.77.3.819

Sewell, W., \& Hauser, R. (1980). The Wisconsin longitudinal study of social and psychological factors in aspirations and achievements. In A. Kerckhoff (Ed.), Research in the sociology of education and socialization (Vol. 1, pp. 59-100). Greenwich, CT: JAI.

Shahimi, F., Heaven, P., \& Clarrochi, J. (2013). The Interrelations among the perception of parental styles and psychological well-being in adolescence: A Longitudinal study. Iran J. Public Health, 42, 570-580.

Sophia, C. (1998). Expanding the knowledge of parental involvement in secondary education: Effects on high 
school academic success. Center for Research on the Education of Students Placed at Risk, Report No. 27, 41.

Steinberg, L., Elmen, J. D., \& Mounts, N. S. (1989). Authoritative parenting, psychosocial maturity, and academic success among adolescents. Child Development, 60, 1424-1436. http://dx.doi.org/10.2307/1130932

Steinberg, L., Lamborn, S. D., Dornbusch, S. M., \& Darling, N. (1992). Impact of parenting practices on adolescent achievement: Authoritative parenting, school involvement, and encouragement to succeed. Child Development, 63, 1266-1281. http://dx.doi.org/10.2307/1131532

Steinberg, L., Mounts, N., Lamborn, S., \& Dornbusch, S. (1991). Authoritative parenting and adolescent adjustment across various ecological niches. Journal of Research on Adolescence, 1, 19-36.

Stevenson, D. L., \& Baker, D. P. (1987). The family-school relation and the child's school performance. Child Development, 58, 1348-1357. http://dx.doi.org/10.2307/1130626

Sui-Chu, H. E., \& Willms, J. D. (1996). Effects of parental involvement on eighth-grade achievement. Sociology of Education, 69, 126-141. http://dx.doi.org/10.2307/2112802

Vellymalay, S. K. N. (2013). Relationship between Malay parents' socioeconomic status and their envolvement in their children education at home. Journal of Social Sciences and Humanities, 8, 98-108.

\section{Copyrights}

Copyright for this article is retained by the author(s), with first publication rights granted to the journal.

This is an open-access article distributed under the terms and conditions of the Creative Commons Attribution license (http://creativecommons.org/licenses/by/3.0/). 